\title{
Midwife roles to decline maternal mortality rate
}

\author{
Ambar Dwi Erawati, Rinayati, Sri Wahyuning \\ Institute of Health Science Widya Husada, Semarang, Indonesia
}

\begin{tabular}{l} 
Article Info \\
\hline Article history: \\
Received Dec 5, 2019 \\
Revised Jan 11, 2020 \\
Accepted Feb 22, 2020 \\
\hline
\end{tabular}

\section{Keywords:}

Childbirth assistance

Delivery assistance

Maternal mortality rate

Midwives

\begin{abstract}
In order to reduce maternal mortality in Central Java, this Province has a superior program which is called $5 \mathrm{Ng}$ (Jateng Gayeng Nginceng Wong Meteng/Central Java Glad to See Pregnant Women). Implementation of childbirth assistance in Semarang and Kendal districts in order to reduce maternal mortality has its own model. Based on the preliminary survey, the maternal mortality rate in Semarang and Kendal regencies has decreased. This research aimed to explain the implementation of delivery assistance by midwives in the framework of accelerating reduction in maternal mortality. This study used a qualitative approach with descriptive analytical specifications. Research subjects were midwives in Semarang and Kendal Regencies. Data collection method was conducted by direct in-depth interview. Normal childbirth assistance in Semarang Regency is carried out at the Midwife Independent Practice, Village midwife practice, at the village public health center and public health center with delivery assistance of at least four hands (two midwives). In Kendal Regency normal delivery assistance is performed at first health facility.
\end{abstract}

This is an open access article under the CC BY-SA license.

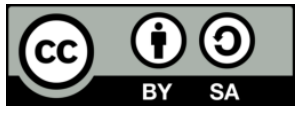

\section{Corresponding Author:}

Ambar Dwi Erawati, Midwifery Study Program,

Institute of health Science Widya Husada Semarang,

Subali Raya Road, Krapyak, Semarang, Central Java 50146, Indonesia.

Email: ambarerawati@gmail.com

\section{INTRODUCTION}

Maternal Mortality Rate (MMR) in Indonesia is still relatively high. From the data of the Republic of Indonesia Ministry of Health in 2016 recorded 305 mothers died per 100,000 live births [1]. Indonesia is a developing country, where the maternal mortality rate is still high, it is because the service coverage is still low and social determinants [2-4]. In Central Java, the maternal mortality rate in 2017 reached $88.58 \%$ surpassing the target of $90 \%$ SDGs. This is inseparable from the flagship innovation program in Central Java that has been in place since 2016, which is the flagship innovation program in accelerating the decline in maternal mortality, which is $5 \mathrm{Ng}$ (Jateng Gayeng Nginceng Wong Meteng). The $5 \mathrm{Ng}$ program is carried out in 4 phases, namely the phase before pregnancy, pregnancy, childbirth and the puerperium $[5,6]$.

In Semarang Regency the number of maternal deaths in 2015 was 16/100,000 live births, in 2017 there were 15/100,000 live births. And in Kendal Regency, the maternal mortality rate in 2017 ranked the third highest mortality rate in Central Java, namely 25 maternal deaths, in 2018 there were 18 maternal mortality rates [6]. Midwives as the spearhead of the health service personnel who are in charge of assisting childbirth, have an important role in helping to reduce the MMR. Midwives in Kendal District in 2018 were 84 midwives. And in the Regency of Semarang as many as 83 midwives who both work as village midwives or PTT $[1,7]$. 
Semarang and Kendal Regencies are Regions in Central Java Province. Topographically, it has a different character in Kendal Regency, which consists of lowland areas (Coastal) and highlands (Mountains). While, Semarang Regency is a highland and hilly region [8, 9]. Based on a preliminary survey conducted by researchers in Semarang Regency, midwives in assisting childbirth were conducted at the puskesmas or PMB, whereas in Kendal Regency according to the midwife who was met, midwives assisting childbirth must perform at Puskesmas. Looking at data from the Profile of the Central Java Provision Health Office, the Maternal Mortality Rate in Semarang and Kendal Regencies has decrased [1]. This study aims to describe the implementation of delivery assistance by midwives in order to accelerate reduction in maternal mortality

\section{RESEARCH METHOD}

\subsection{Data sources}

Primary data in this study is the delivery assistance conducted by midwives in Semarang and Kendal Regencies, Central Java Province. The data collection method was carried out by interviewing midwives in the region of Semarang and Kendal Regencies of Central Java Province with Triangulation by the chairman of Kendal Regency IBI and the chairman of Semarang Regency IBI.

\subsection{Data subyek}

Subjects of this study were practicing midwives who were in Semarang Regency working area and practicing midwives who were in Kendal Regency assisting childbirths. The object in this study was the implementation of delivery assistance by midwives.

\subsection{Data analysis}

The approach method used in this research is qualitative. With descriptive analytical research specifications that systematically describe and analyze the implementation of childbirth assistance conducted by midwives in Semarang and Kendal Regencies, Central Java Province. Analysis was done by qualitative normative and inductive methods

\section{RESULTS AND DISCUSSIONS}

\subsection{Result}

\subsubsection{Implementation of childbirth assistance in Semarang Regency}

- Childbirth assistance location

Based on the results of interviews with research subjects, in this case midwives practicing in Semarang Regency, normal delivery assistance is done at the Village Midwife Practice, Midwife Independent Practice, at Polindes, at Puskesmas. In order to facilitate patients regarding financing for delivery assistance was covered by the National Health Insurance midwives in the region of Semarang Regency collaborated with pratama health facilities.

- Childbirth assistance prosedur

Based on the results of interviews with research subjects in this case midwives practicing in Semarang Regency, normal delivery assistance was carried out in accordance with the APN (Asuhan Pertolongan Persalinan Normal/Normal Childbirth Assistance Care). By providing delivery assistance according to APN, it means that 5 aspects of childbirth assistance are carried out, those are: making clinical decisions, caring for mothers and babies, preventing infection, recording (medical records) of caring for delivery, referral to maternal cases and newborn complications. Midwives in Semarang Regency in helping with normal deliveries are always done at least 2 midwives or so-called 4 (four hands) whose aim is to facilitate handling in the event of an emergency. Every time a patient arrives to give birth, the intended midwife contacts the closest midwife's friend for joint delivery assistance.

\subsubsection{Implementation of childbirth assistance in Kendal Regency}

- Childbirth assistance location

Based on the results of interviews with research subjects in this case midwives practicing in the region of Kendal Regency, midwives said that normal delivery assistance was done at Puskesmas or at the hospital. Midwives who have an Independent Practice permit do not provide childbirth assistance at Home, even if there are patients who come to give birth, midwives directly ask patients to go to Puskesmas without making a referral. 
- Childbirth assistance prosedur

Delivery of assistance is minimal conducted at PONED Puskesmas or rumah Mampu bersalin (Maternity Capable house) assisted by doctors, midwives and assisted by nurses.

\subsection{Discusion}

Maternal mortality in accordance with the results of Nurul Aini's study entitled "Risk factors for maternal mortality" causes of maternal mortality rates are pregnancy complications, complications of complications and history of the disease. However, there are several other causative factors that contribute to maternal mortality, which in his research there are three determinants of maternal mortality rates, namely close determinants, intermediate determinants and distant determinants. Close determinants are complications of pregnancy and childbirth. Determinants include disease history, antenatal examination, mode of delivery, and late referral. Distant determinants of economic, social, and cultural conditions in the neighborhood of pregnant women, education level, employment status, and family income are not related to maternal mortality [10].

Delay in referral is an indirect maternal mortality factor that is proven to be significant for both maternal and infant mortality rates $[7,10]$. The most ideal childbirth assistance is at health facilities where the availability of equipment and health workers is ready at any time during an emergency. Minimum health facilities that serve Obstetric and Basic Essential Neonatal Services (PONED) [11].

Research results showed that the Independent Practice Midwife was a favorite place for delivery assistance by patients [12]. In accordance with the results of Amdad's research and his theme entitled "Don't Ma'am, I Give You Birth At Home Only":Qualitative Study on Searching for High-Risk Pregnancy Care Services at Waruroyom Health Center in Cirebon Regency, West Java Province "shows that pregnant women will look for delivery assistance with a choice at midwives, community Health centers and the last option is Hospital because midwives are closer and get family support [13].

Midwives in Semarang Regency delivered childbirth assistance at the Midwife's Independent Practice, Village Midwife Practice, Puskesmas, Polindes where childbirth assistance was carried out jointly by at least 2 midwives. Midwives in Kendal Regency did not provide childbirth assistance at pratama health facilities where there were doctors, midwives, and nurses in the pratama health facilities. Even if there were patients who come to midwife independent practice, the midwife immediately recommended the patient to Puskesmas without giving a referral.

Health workers play an important role in reducing maternal mortality, especially in community empowerment and partnerships [14. 15]. In addition, decentralization in the health sector has good potential in the efforts of health services [16, 17]. In accordance with their authority, midwives have the authority to deliver labor both at PMB and at other eligible health facilities [18-20]. Midwives in carrying out their duties are required to always improve their professional quality, especially in assisting childbirth [21].

Normal childbirth assistance by midwives in Semarang and Kendal districts is part of the implementation of planning in an effective strategic effort for policy holders to accelerate the reduction in maternal mortality [22]. In accordance with Law No. 23 of 2004 concerning Government, it is stated that compulsory affairs which become the authority of regional governments are Health in this case the provision of health facilities [23]. In Kendal District, there is a PONED community Health centers to facilitate the delivery of normal childbirth and to turn a community health center that has not yet been PONED into a delivery house in an area far from the PONED community health center.

Maternity-ready houses created by Kendal District and mandatory childbirth assistance in Semarang District are part of the local government's innovation in reducing maternal mortality. Basic obstetric and neonatal emergency services (PONED) in the era of decentralization, regions implement various innovations in accordance with the commitments and potentials of their respective regions. In addition it is necessary to develop policies from the center to the regions, cooperation on all parties related to development, especially civil society [24-28]. Governments in Semarang Regency and Kendal Regency in the context of improving performance in reducing maternal mortality have policies implemented in providing birth assistance by midwives relating to development, specifically [29].

The efforts made by the Semarang regency and Kendal regencies are government efforts to reduce maternal and infant mortality rates through policies. Some districts in Indonesia have had successful experiences in reducing maternal mortality and infant mortality rates with regulations for reducing maternal and infant mortality. The policy is outside the national policy and there are even regions that implement village level policies in order to reduce maternal and infant mortality. In Pasuruan Regency succeeded in reducing maternal, infant and toddler mortality rates and even received an MDG award by lowering Regional Regulations, Regents of Regents, and Village Regulations , regarding KIBBLA (Maternal and Newborn Health [30], While the efforts made by the Kapuas Hulu District Health Office have made Madubulin (the Public Concerned Women) [31] 
Policies will be implemented if the quality and quantity of resources are met. Human resources and financial resources are one of the factors that influence the implementation of a policy [32]. The reduction in maternal and infant mortality rates in line with the SDGs is inseparable from the role of local governments who are closer to citizens, has authority in the use of funds, innovation and local government is the spearhead of providing public services and government programs [33].

According to a researcher, the community has confidence in midwives as birth attendants, midwives also have the authority to conduct normal childbirth assistance, so that normal delivery assistance by midwives may be done by Midwife Independent Practice, practices of village midwives, at Polindes, or at Puskemas but must work with other midwives done by at least 2 midwives so that emergency events can be handled immediately.

\section{CONCLUSION}

Normal childbirth assistance in Semarang Regency is performed at the Midwife Independent Practice, Village Midwife Practice, at Polindes, or at Puskemas with delivery assistance of at least 4 hands (two midwives). Childbirth assistance in Kendal Regency must be done at the First Health Facilities. The community still has trust with the midwife as a helper for childbirth. To facilitate handling if there is emergency state delivery as sistance should be done by midwives in independent practice at least carried out by two midwives.

\section{ACKNOWLEDGEMENTS}

This article is the result of research founded internally by STIKES Widya Husada Semarang.

\section{REFERENCES}

[1] C. for R. and D. of P. H. E. H. R. and D. Agency, Maternal and Child Health Profile 120 Regencies/Cities Locus of AKN MMR. 2019.

[2] M. M. Wai, E. Bjertness, T. T. Htay, T. Liabsuetrakul, and J. Sundby, "Maternal mortality and fertility in Myanmar: State of the art," Int. J. Popul. Stud., vol. 5, no. 1, pp. 27-37, 2019.

[3] G. Putro and I. B. Maisya, "Social Determinants in Maternal Deaths at dr. Abdoer Rahem Regional General Hospital Situbondo District," Glob. Med. Heal. Commun., vol. 6, no. 1, pp. 74-82, 2018.

[4] D. Yulianti, "Improvement Of Program Implementation Target Capacity Preparation Of Labor And Prevention Of Complications (P4K) In The Implementation Of Strategies To Reduce Maternal Mortality Rate (MMR) In Panjang District, Bandar Lampung City,” Sakai Sambayan community Serv. J., vol. 2, no. 1, p. 14, 2018.

[5] S. public relation, "flagship innovation program , 5Ng (JateNG GayeNG NginceNG woNG meteNG)," 2019. Central Java Health Office.

[6] Central Java Health Office, Health Profile of Central Java Province 2018. Central Java Health Office, 2019.

[7] M. T. Chalid and U. Hasanuddin, "Efforts To Reduce Maternal Mortality Rate: The Role Of Health Officers," no. December 2016, 2017.

[8] Kendal Regency Government, “geographical conditions.” Kendal Regency Government, 2019.

[9] Regency Go vernment Semarang, "Topography Semarang Regency Government," Topography Semarang Regency Government. Semarang Regency Government, 2019.

[10] N. Aeni, "risk factors for maternal mortality," Kesmas Natl. Public Heal. J., vol. 7, no. 10, pp. 453-459, 2013.

[11] A. N. Uswatun Khasanah, Esyuananik, "Analysis Of Sociodemography Factors In Taking Decisions For Selection Of Labor Places In Bangkalan Regency,” J. Tradit. Midwifery Heal., vol. 3, no. september, pp. 27-31, 2018.

[12] D. Warganingsih, "Description Of Place Selection And Labor Delivery In Trimester II-III Pregnant Mother In Jatisarono Village Nanggulan Kulon Progo.” midwifery study program Jendral Ahmad Yani Institute of Health Science, pp. 1-42, 2010.

[13] Amdad, Detty Siti Nurdiati, and A. Triratnawati, The gateway to understanding epidemiology, biostatistics, and research methods, 7th ed., vol. 2. DirektoraDirectorate of Health Promotion and Community Empowerment, 2017.

[14] S. U. Chasanah, "The Role Of Public Health Workers In An Effort To Decrease Maternal Mortality Post Mdgs 2015," public Heal. J. Andalas, vol. 9, no. 2, pp. 73-79, 2015.

[15] W. Y. M. Usa, "Efforts To Reduce Maternal Mortality Rate (MMR) In Mulyorejo Community Health Centers Surabaya City," J. Heal. Res. Suara Forikes, vol. VIII, no. 3, pp. 126-134, 2017.

[16] A. M. P. Wiko Saputra, Victoria Fanggidae, "Effectiveness Analysis of Local Policies in Reducing Maternal and Infant Mortality," Kesmas Natl. Public Heal. J., vol. 7, no. 12, p. 531, 2013.

[17] I. Murniati, V., Mulyana, Y. dan Kuswardinah, "Cadre Formation As A Health Efforts All Depends Mother And Child Mortality In Village Dunguswiru And Neglasari District Blubur Limbangan Garut,” J. Sci. Technol. Appl. Soc., vol. 2, no. 1, pp. 60-64, 2013.

[18] Ministry Of State Secretariat Of The Republic Of Indonesia, "Law of the Republic of Indonesia Number 4 of 2019," vol. midwifery, no. 004078. Republic of Indonesia, 2019. 
[19] M. O. S. S. O. T. R. O. Indonesia, "Regulation Of The Minister Of Health Of The Republic Of Indonesia Number 28 Of 2017," 2017.

[20] S. Purnamasar, "Implementation Of Reducing Maternal Mortality Rate (MMR) Policy In Banyumas District," Law Econ. Dev., vol. 6, no. 1, pp. 1-20, 2018.

[21] R. Yuningsih, "Midwifery Profession In Policy Development Efforts To Improve Maternal and Child Health Services Rahmi," Cent. Expert. Res. DPR RI, pp. 63-76, 2016.

[22] R. Eftekhar-vaghefi, S. Foroodnia, and N. Nakhaee, "Gaining Insight into the Prevention of Maternal Death Using Narrative Analysis : An Experience from Kerman, Iran,” vol. 1, no. 4, pp. 255-259, 2013.

[23] R. Indonesia, "Laws Of The Republic Indonesia Number 32 Of 2004.” Republic, Indonesia, pp. 1-249, 2004.

[24] T. Rachmawati, "Poned Health Center Implementation Innovation In The Efforts Of Acceleration Of Reducing Poned Health Center Implementation Innovation In The Efforts Of Acceleration Of Reducing Maternal Mortality Rate (MMR) And Infant Mortality Rate Figures In Three (Thr," Heal. Res. Bull., vol. 13, no. 17, pp. 109-115, 2010.

[25] A. Achadi, "Next Steps Accelerate Reduction in Maternal Mortality in Indonesia," Natl. J. Public Heal., vol. 4, no. 4, pp. 147-153, 2010.

[26] T. Laksmiarti and B. Roosihermiatie, "Policy In Efforts To Reduce Maternal Mortality Rate (MMR) And Infant Mortality Rate Figures In 5 Districts /south Kalimantan Province," Heal. Syst. Res. Bull., vol. 10, no. 2, Apr, 207AD.

[27] E. Tambun and M. Hasanbasri, "The Evaluation Of Implementing Delivery Care Policy For Poor Community By Private Midwife Practice In Tanjungpinang Municipality," Indones. Heal. policy J., vol. 02, no. 02, pp. 61-70, 2013.

[28] P. women leadership and Inclusive and and sustainable natural resource governance Gender-based, "Reducing Maternal Mortality (Editorial).” Women Reserch Institute, 2019.

[29] C. Pitocco and T. R. Sexton, "Measuring hospital performance using mortality rates: An alternative to the RAMR," Int. J. Heal. Policy Manag., vol. 7, no. 4, pp. 308-316, 2018.

[30] R. H. Nurrizka and W. Saputra, Policy Update Direction and Strategy of the Declining Number of Policies Maternal Mortality (MMR), Infant Mortality Rate (IMR) and Toddler Mortality Rate (AKABA) in Indonesia, 1 st ed. Indonesia, 2013.

[31] Sali Susiana, "Mortality: Causes Factors And Handling Efforts.” DPR RI Expertise Research Center, 2015.

[32] Mhd. Wahyudin Mi'raj, "The Implementation of the Dear Mother Movement (GSI) in Tasik Seminai Village, Koto Gasib District in 2015," J. Chem. Inf. Model., vol. 4, no. 1, pp. 1-15, 2017.

[33] M. B. Hoelman, B. T. P. Parhusip, S. Eko, S. Bahagijo, and H. Santono, "Sustainable Development Goals-SDGs Guide for Local Government (City and Regency) and Regional Stakeholders," in Sustainable Development, International NGO Forum on Indonesian Development (INFID), 2016, pp. 1-92. 